\title{
WATER, WHITE TIGERS AND CORRUPT NEOLIBERALISM: CONTROVERSIAL ENTREPRENEURS IN RECENT FICTION FROM THE SUBCONTINENT ${ }^{1}$
}

\author{
ISABEL ALONSO-BRETO \\ Universitat de Barcelona \\ alonsobreto@ub.edu
}

Received: $18-11-2014$

Accepted: 27-01-2015

\begin{abstract}
Water has traditionally held a variety of metaphorical meanings in literature. Mostly, however, it has been deployed as a purifying element, endowed with the virtues of cleansing and renewing both persons and situations. Such perception of the substantiating role of water finds an echo in the main Indian cultures, both Hinduism and Islam. This article argues that the traditional metaphorical use of water as connected to renovation is very present in contemporary fiction of South Asian origin, yet its main argument is that this idea of renovation, which has traditionally been perceived as positive, is not necessarily ridden with celebratory aspects in the novels under discussion. Rather, water plays in these works controversial if not highly problematic roles. The works discussed are Aravind Adiga's The White Tiger (2008), Chetan Baghat's Revolution 2020 (2011), and Moshin Hamid's How to Get Filthy Rich in Rising Asia (2013), novels whose main characters are fictional representations of the pioneers of their generation, in all cases moving from rags to riches at the expense of surrendering to immorality or corruption. Besides entailing a sharp criticism of the indiscriminate neoliberal practices which are enriching certain sectors of Asian societies, these novels denounce the severe misuse of water sources, essential for the daily routines of millions of people who, with the changes brought about by rather abrupt processes of modernization, are deprived of access to their traditional means of subsistence.
\end{abstract}

KEYwORDS: Aravind Adiga, Chetan Baghat, Moshin Hamid, water, neoliberalism, corruption

RESUMen Agua, Tigres Blancos y Neoliberalismo Corrupto:Emprendedores Dudosos en la Nueva Literatura del Subcontinente

En la tradición literaria se ha atribuido al agua una gran variedad de significados. Mayormente, sin embargo, el elemento líquido se ha significado como un principio purificador, poseedor de las virtudes de limpieza y renovación de personas y situaciones. Este rol sustancial del agua encuentra eco en las culturas mayoritarias de la India, Hinduismo e Islam. Este artículo sugiere que la imagen tradicional del agua como vehículo de renovación está muy presente en la fícción contemporánea del Subcontinente, pero mientras que la idea de renovación se ha percibido generalmente como positiva, en las novelas analizadas el agua no se presenta asociada con aspectos celebratorios sino que, por el contrario, juega un papel controvertido si no abiertamente negativo. Las novelas exploradas son The White Tiger (2008), de Aravind Adiga, Revolution

\footnotetext{
${ }^{1}$ This research is part of the project "Relations and Networks in Indian Ocean Writing," funded by the Spanish Ministry of Economy and Competitiveness (FFI2012-32626).
} 
2020 (2010), de Chetan Baghat, y How to Get Filthy Rich in Rising Asia (2013), de Moshin Hamid. Los protagonistas de estas novelas son una representación ficticia de los pioneros de su generación, y en todos los casos se enriquecen a costa de llevar a cabo acciones inmorales o corruptas. Si por un lado estos trabajos ofrecen una crítica acerada de las prácticas neoliberales que están enriqueciendo a ciertos sectores de las sociedades en cuestión, también denuncian un manejo incompetente del agua. Este es un bien esencial para las actividades diarias de millones de personas, quienes, sin embargo, con los profundos cambios que conllevan estos abruptos procesos de modernización, se ven privadas de acceso a sus medios de subsistencia tradicionales.

Palabras Clave: Aravind Adiga, Chetan Baghat, Moshin Hamid, agua, neoliberalismo, corrupción

Probably without exception, water has been associated with relevant values in human societies. As Yves Bonnefoy remarks in his prestigious Dictionary of Mythologies (2010), in Asian cultures water is connected to myths of origin and of fertility, as well as to funeral rites. ${ }^{2}$ Bonnefoy acknowledges, however, that most often water has been associated with purity. Thus, it has been frequently endowed with the virtues of cleansing and renewing the world and its people. ${ }^{3}$ It is precisely for this reason that, in the cultures he refers to, it was often forbidden to pollute the water, be it washing dirty clothes in it, defecating, or even bathing oneself in clean waters. In Hindu culture water is paramount; suffice it to remember the vital -and somewhat clichéd-images of people washing their clothes and making their morning ablutions alongside the ghats of the main Indian rivers, most famously Mother Ganga. While water is revered in Indian cultures, Bonnefoy's annotation about the traditional directive to avoid the pollution of water is a productive entry into the images of water as presented in the works I shall discuss in this article. In these novels the liquid element is dramatically tainted, at both a symbolic and a material level.

In contemporary South Asian writing, water in different forms is endowed with complex and varied metaphorical meanings, yet all of them invariably connected to the idea of transit. The obvious quality of fluidity enables this connection, as it suggests flow and movement. Yet water can also take the form of stagnant pools where the possibility of movement, circulation, or transit appears as remote. One can recall the

\footnotetext{
${ }^{2}$ He refers particularly to the Mongol and Turkish ones.

${ }^{3}$ On the purifying virtues of water, see also Gaston Bachelard's seminal essay Water and Dreams: An Essay on the Imagination of Matter.
} 
image of the dark pond of putrid water in the backyard of the household that Anita Desai describes in her novel Clear Light of Day (2003), full of metaphorical implications. Against this stagnant image, in the novels I shall be discussing water figures as a metaphor of transit.

This transit is one from tradition to modernity. This very idea, like the image of the Ganga ghats, has become a cliché like the Ganga images, and so it needs qualifying. The modernity reflected in these works is characterized by several features: its vertiginous pace; its virtual inescapability; the excessive demands it places on human beings; and, last but most important, its extreme mercantilist accent. As follows from the stories I shall be discussing, and others thematically connected to these and set in various parts of the continent, ${ }^{4}$ Asian societies are taking a harshly materialistic turn, where people's lives are highly influenced (and paradoxically, often deteriorated) by quickly evolving economies. As the writers of these critical novels expose, young and not so young individuals have to juggle their choices to the best of their abilities in order to find their way through a world which increasingly judges them exclusively for their economic achievements. Indeed, none of these novels' main characters want to be left behind on the promising road to economic success, which has become the dominant ethos in their respective surroundings.

Economic success is demanding and expensive; thus the novels present a state of affairs where bribery and corruption are paramount: indeed they are seen as the pre-condition for social success. Escaping the lot of endemic destitution and leaving behind the anonymous mass, which according to Aravind Adiga's narrator in The White Tiger cannot even exercise the basic right to vote in the so-called "World's largest democracy", seems to demand a certain moral ambiguity, if not complete lack of scruples. But it is precisely this ethical laxity that eases the way into a social status that rids the subject from conscripting burdens of the past, fundamentally poverty, but also

\footnotetext{
${ }^{4}$ Pankaj Mishra (2013) mentions Malaysian Tash Aw's Five Star Millionaire, Yu Hua's Brothers, set in China, and Randy Bodagoya's Beggar Feast, set in Sri Lanka.
} 
other drawbacks such as low caste, remote birth-place, or the lack of minimal schooling, let alone tertiary education.

The careful depiction of the dubious means through which the main characters in each of these novels amass their fortunes provides a bleak depiction of Asian societies, and more generally of a globalized world mostly controlled by rampant capitalism. In a review entitled "Asia: The Explosive Transformation" Pankaj Mishra discusses some Asian novels which respond to the same narrative and ideological pattern. He claims indeed that in our time "the literary vision of capitalism red in tooth and claw is likely to be found mostly in fiction set in contemporary Asia" (Mishra 2013). Mishra's review is somewhat comforting, insomuch as he recalls that European and American literature produced in the nineteenth century was also full of ambitious characters who managed to rise above the rest and amass amazing fortunes through dubious means, and that this was only the first part of a story that later on became less carnivorous: "Robber barons dominated the early phases of American industrial capitalism before the oil, steel, and railway tycoons, and their family members, descendants, and cronies, gave way to relatively transparent, shareholder-friendly companies" (Mishra 2013, n.p.n.). According to Mishra's view, then, some need to get rich first in order for others to share their profits later on, and create more democratic systems of wealth distribution. This seems to suggest that the present situation in Asia, in which society can be rightly described as "a jungle" divided into two castes, "those who eat vs. those who are eaten up" (Adiga 2008: 64) as we read in The White Tiger, is only a temporary step towards a more egalitarian situation. Yet it is difficult to obviate the huge social inequalities which keep plaguing American and European societies two centuries after the vertiginous decades of the Industrial Revolution and its aftermath, when the novels Mishra refers to were written. And in the India of the present day, in spite of the nation's enrichment (India being one of the BRICS nations whose economies are evolving dramatically), the situation is far from improving for the mass of the people. Mishra himself reminds us that "in "rising" India, ... while a handful of Indian billionaires increased their share of national income from less than 1 percent in 1996 to 22 percent in $2008, \ldots$ the number of malnourished children, nearly 50 percent, has barely altered” (Mishra, n.p.n.). It 
appears that any optimism about an impending redistribution of wealth and more equitable societies in Asia should be moderate.

Many contemporary Asian novels raise important ethical questions about this transit into modernity-as-wealth or, more accurately, modernity-as-unevenly-distributed wealth. The critical discussions of these works frequently focus on ethical cum socioeconomic questions, and, more generally, reflect upon the "rising Asia" (Hamid 2013) scenarios that these novels illustrate. Lena Khor's analysis in "Can the Subaltern Right Wrongs? Human Rights and Development in Aravind Adiga's The White Tiger", for instance, connects the 2008 Man Booker Prize winner to concepts as enlightening as Spivak's idea of a "World Class Apartheid" (Khor 2012: 43), that the novel would denounce, or to social theories like Sankara Krishna's "Underdevelopment School of Thought," inspired by the Dependency Theories which gained currency in the 1960s and which maintained that the 'developed' countries were richer than the 'Third World' countries precisely because they developed at their expense (Khor 2012: 45). Indeed, the main characters in these stories are poor because their families have been robbed, not only symbolically but quite literally in all cases, and thus it may appear as justifiable that, when they manage to redress this grievance, these men would do so at the expense of robbing others. Lena Khor also refers to Gustavo Esteva and Madhu Suri Prakash's "One Third World/Two Thirds World" theory, where the old divide between the First and Third worlds is replaced by another configuration, in which the elites of the former Third World and the newly impoverished masses in the West have swapped places, and are filed next to those who either "have" or "do not have" as much as them, regardless of their geographical location (so that we have pockets of the First World in the Third World and viceversa). In short, Khor suggests that The White Tiger "captures the palimpsestic way in which legacies of underdevelopment overlay themselves upon themselves, individuals, communities and nations" (Khor 2012: 45). Thus, this critic's insightful analysis of the criticism of the uneven economic structures in The White Tiger 
could successfully apply to the rest of novels in question, all three of which respond to what has been labeled as the "condition-of-India-novel" (Detmers 2011). ${ }^{5}$

The focus of the novels' critique is on the figure of the successful self-made entrepreneur. All three protagonists, Aravind Adiga's Balram Halway, Chetan Bhagat's Gopal Mishra and the anonymous narrator of Moshin Hamid's How to Get Filthy Rich in Rising Asia, manage to rise from rags to riches through dubious means. And, interestingly, the three novels present ingenious narrative strategies that allow the use of the first or second person, and thus present the entrepreneur's experience from a very personal perspective: The White Tiger consists of a collection of letters written to the Chinese (former) Prime Minister, Wen Jia Bao; Revolution 2020 reproduces verbatim a first-hand confession made to the writer himself -whose real name appears in the narrative. Somewhat more sophisticated, How to Get Filthy Rich in Rising Asia replicates the structure and formal rhetoric of a self-help book, narrating the facts in the second person in the form of advice, yet still, like the others, from a very close perspective. Of course this allows the reader a very close glimpse of their many illicit activities, and therefore it invites harsh judgment and, simultaneously, a degree of leniency in the final verdict. It is my claim that, while the novels' criticism of the system is implacable, the take on these characters is attractively ambivalent: in all cases the narrative shape aims at not only narrating but also justifying their controversial achievements. The narrative strategies entail a clear invitation to empathize, if not fully sympathize, with each of them. In a way, all three are forced to succeed in order to survive, and the reader can only sanction this. Further, we are induced to admire them, to share the joy of their achievement with a compromised sense of guilt and lightness. In different ways, the three narratives parody the image of the successful entrepreneur as projected by the self-help books that at present are best-sellers in India and elsewhere (Venugopal 2011). A curious coincidence -or perhaps not quite so coincidental-, is that one of the world gurus of entrepreneur leadership, Robin Sharma, a Canadian of Indian ancestry who authored the hugely successful The Monk Who Sold His Ferrari (1997), published in 2011 his second international hit: Be a Leader without a Title. This title

\footnotetext{
${ }^{5}$ For further critiques of the pernicious effects of the expansion of neoliberal politics as reflected in The White Tiger see also Al-Dagamseh 2013, Joseph 2012 and Thoker 2012.
} 
echoes the condition of these three main characters, none of whom received a university degree - nor finished their primary school in two cases. The coincidence is remarkable also because of the fact that when he manages to change his destiny through killing his master, the white tiger Balram Halway will change his first name to that of his master: Ashok, choosing, again perhaps by chance, the surname Sharma.

Water accompanies and illustrates these social trajectories, and it is played out through different tropes, its fluidity always suggesting the continuous evolution of society -its transit. It some cases, the liquid element features as a highly symbolic testimony of the situation explored, while in others it is exploited as an instrument of self-improvement. The novels play on the huge symbolic meaning of water in Hinduism and Islam, and at the same time bear upon the significant shortage of water that Asian societies are suffering because of the combined realities of "growing populations, rapid urbanization, and competing demand for water for agriculture, energy, industrial, and domestic use."6 Water is a key issue in present Asian politics, and as such it is one of the Focus Areas of the Asian Development Bank, an institution fully aware of the kind of problems tackled by these novels:

\begin{abstract}
Annual per capita water supplies have been declining at alarming rates, with some parts of Asia and the Pacific already below 1,000 cubic meters per capita per year. The gap between demand and supply is widening. At an aggregate level, it is forecast to get steadily worse, indicating increasing water shortages. This gap will lead to increased competition between water users-farmers, energy producers, households, and businesses. $^{7}$
\end{abstract}

Besides reporting on unscrupulous means of self-enrichment, and criticising severe wealth inequality and corruption in quickly developing Asian societies, the novels tackle the crucial matter of water shortage and pollution, and the subsequent necessity to clean and distribute it, a pressing issue at global, Asian and Indian levels.

\footnotetext{
${ }^{6}$ http://www.adb.org/sectors/water/overview. Access 16 October 2014.

${ }^{7}$ http://www.adb.org/sectors/water/overview
} 
Aravind Adiga's The White Tiger (2008) is organized around a crucial reference to the river Ganga. Its protagonist, Balram Halway, has a first and decisive epiphany at his mother's funeral, which he attends as a child by the waters of the holy river. As he sees that his mother's corpse is being devoured by "a giant oozing mound of black mud" (Adiga 16) in the Ganga riverbank, he becomes suddenly aware that the idea of circularity that governs Hindu philosophy and life means that he will have to resign himself to his lot of destitution, since "nothing would be liberated here" (Adiga 2008: 16). This episode marks the beginning of Balram's road to awareness of and reaction against the life-long burden of having to be a serf for others. Balram writes the letters which compound his narrative as an adult from the perspective of his new identity as Ashok Sharma, which he achieves, as announced above, after the feat of murdering his master and robbing him of a bag full of money. With that money he became founder and $\mathrm{CEO}$ of a thriving taxi company in Bangalore, specialized in driving the employees of foreign outsourcing companies to and from their workplaces at untimely hours. Ashok Sharma thus grows inordinately rich. Crucially, he manages so well because he hasn't broken the chain of economic bribery he learnt about when he was a servant for powerful masters. Indeed he keeps acting in corrupt ways himself, which quickly boosts his way into affluence. Admittedly, however, he introduces small changes in his behavior as an employer, which perhaps signal, albeit weakly, the beginning of change, such as signing work contracts for his employees that he fully respects, and also responding to his responsibilities, of whatever kind, as head of his taxi company. ${ }^{8}$

Yet, in spite of his success, Balram/Ashok's view of the state of affairs in Indian society is derisive, and his criticism points at Mother Ganga as the great signifier of decadence. Indeed, to a great extent the great national narrative of India is constructed around the image and values of the sacred river, a refrain which Balram repeats quite ironically: "Mother Ganga, daughter of the Vedas, river of illumination, protector of us all, breaker of the chain of birth and rebirth" (Adiga 2008: 15). Against this received narrative, Balram/Ashok posits the sordid reality of the river as being "full of faeces, straw, soggy parts of human bodies, buffalo carrion and seven different kinds of industrial acids"

\footnotetext{
${ }^{8}$ For instance, when one of his drivers hits a cyclist and kills him, he takes on the responsibility, and even visits the victim's family to compensate them economically, whereas as a driver he was induced to take the responsibility for a hit-and-run caused by one of his masters.
} 
(Adiga 2008: 15). This image synthesizes the novel's verdict on India. Yet there is room for ambivalence, because in spite of the huge critical irony permeating the book, the fact that this character manages to rise above the rest and succeed in breaking out of "the Great Indian rooster coop", the ironic metaphor he finds to refer to the state of destitution and servitude in which the majority of people of India are forced to subsist is presented, on the whole, not without sympathy. One of the strengths of The White Tiger is precisely the way in which Balram/Ashok's narrative carefully constructs an apology for his heinous crime. The novel eventually suggests that his is a necessary reaction, since it appears as the only possibility to escape a fate of rampant exploitation, a feat that only somebody as exceptional as this character, a true White Tiger which only appears once in a generation, could achieve. Balram/Ashok's story of success recalls Frantz Fanon's ideas about violence as necessary to advance the anti-colonial struggle and achieve freedom. Indeed, Balram's violent transit from serfdom to mastery of self and his change of identity into Ashok recalls Fanon's statement that "violence is man re-creating himself" (Fanon 1963: 40). Also Michel Foucault has been explicit about the moral obligation humans have to react against the frozen power structures that exploit and immobilize them:

We have to rise up against all forms of power-but not just power in the narrow sense of the word, referring to the power of a government or of one social group over another: these are only a few particular instances of power. Power is anything that tends to render immobile and untouchable those things that are offered to us as real, as true, as good. (Foucault 1980, n.p.n.)

As a driver and servant, Balram lives in close contact with the benefits of wealth, and as such he cannot be indifferent to them. It is difficult to judge his crime without taking into account the pitiful picture of the homeless or slum-dwellers, as well as the heartless exploitation of the servants he has presented us with earlier on, and thus the door to ethical ambiguity is left ajar. 
All in all, Balram's symbolic and physical transit is one from tradition in "the Darkness," a heavily oppressive reference to ancestral India embodied in his mother's battered corpse being burned in the Ghats of the sacred/filthy river, to modernity in "the Light," a new site of freedom, again both literal and metaphorical, where he can choose the type of person he wants to be -a world ripe with possibilities symbolically embodied by his numerous chandeliers.

Mother Ganga features even more prominently in Chetan Baghat's Revolution 2020. Love. Corruption. Ambition. (2011). Actually, the novel is dedicated "to the city of Varanasi" and "to the holy river." Here we have another "rags to riches" story in which the main character thrives in spite, or precisely because of his lack of scruples. Born in Varanasi, Gopal Mishra grows up as a motherless orphan living with his father, who is affected by tuberculosis, a pattern which reproduces exactly that of Balram Halwai/Ashok Sharma (the metaphor of the dead mother is actually recurrent in Indian Writing in English). Gopal has two close friends, Raghav and Aarti, the second of whom he falls in love with as a teenager. When the time comes to choose a professional career, he joins the thousands of young Indians attempting to pass the greatly coveted AIEE (All Indian Engineering Entrance Exam) and IIT JEE (Indian Institute of Technology Joint Entrance Exam). Failing to get a qualification that would allow him to enter any Engineering Faculty while Raghav obtains an excellent grade, Gopal sees himself forced by his father to repeat the attempt, with the sad result that he fails again while his father has become heavily indebted. Meanwhile, Aarti has got engaged to Raghav, and Gopal is mortally jealous.

Like Balram, Gopal's choice of rising to success through means not altogether transparent is also justified. Not reaching a sufficiently high grade in AIEEE was not his fault, and while he was willing to enter another faculty so as to get any university degree even if it was not engineering, and work part time to cover the home expenses, his father forced him to try a second time, thus fully debasing the boy's sense of selfesteem. Gopal's second failure means still bigger distress, but worse for him is his father's disillusion. Actually, the father will die soon afterwards, leaving Gopal with the sad remorse that his failure has contributed to precipitating his father's demise, rather a 
heavy burden to live with for a barely twenty-year-old youth. The father's fixation that Gopal should become an engineer testifies to India's present obsession with technology: in most circles, engineering is seen as the surest, perhaps the only means to find a good job.

Gopal's story is set in Varanasi, the spiritual centre of Hinduism. The rampant corruption that is going to be exposed thus gains deep meaning, symbolically spanning the subcontinent. As a teenager, Gopal often takes Aarti to row on the river Ganga. They spend placid hours in a hired boat until sunset, routinely accompanied by the busy ghats in the near distance, seeing the cremation fires and the aarti lamps at sunset. The holy river appears as a comfort zone for those who live in Varanasi, and also as a signifier of possibilities. Soon after his double failure and his father's death, Gopal meets Shukla-Ji, a corrupt MLA (Member of the Legislative Assembly) whose power to achieve anything through raw bribery seems to have no limits. Shukla-Ji helps Gopal settle a land dispute his father had maintained with his own brother, who for decades had swindled him in a callous effort to take over his land portion. The violent means Shukla-Ji's men employ to get rid of Gopal's uncle's grip on the land are, therefore, perceived as a variant of poetic justice, and this apologetic tone somewhat applies to the whole of Gopal's socio-economic progression. The first person narrative contributes to this effect. As immediate listeners we sympathise with his misapprehensions as he becomes the wealthy director of a private Engineering College, built on his land with irregular funding provided by Shukla-Ji. Gopal's growing fortune is built both on his daily work (he toils hard to ensure the success of his college) and on the envelopes he soon learns to administer right and left in order to get the right permissions to construct, etc. Gopal is hardly aware that GangaTech, as the college is named, is used by the mendacious MLA as a trust to distract public attention from a possible scandal around the Ganga Action Plan, whereby he had diverted to his pocket a huge amount of public funds that were destined to tidy up the holy river. If real, this fictional plan would have been part of current policies intended to alleviate the fact that "in large parts of Asia and the Pacific, more than $80 \%$ of the volume of untreated wastewater leaches into accessible freshwaters and coastal waters [with the result that] public health 
consequences are significantly affecting lives, livelihoods, and productivity." "Yet despite Shukla-Ji's efforts to keep this blatant robbery hidden, the uncomfortable truth is disclosed by Raghav, who, ironically, has become a journalist and not an engineer. Raghav publishes an article with the results of his investigation entitled "MLA makes money by making holy river filthy" (Baghat 234), whose readers learn that their political representative's greed is the reason why the sewage systems around Varanasi have so completely collapsed that illness is quickly spreading and causing the death of hundreds of children and elderly people. As Gopal himself formulates it, "a politician stealing is bad enough, but to rob from the holy river is the worst sin" (Baghat 2011: 236).

Shukla-Ji is forced to resign and is imprisoned. Now, the turning point in Gopal's life comes when, given the chance to continue his mentor's career in politics, he eventually decides to give up this possibility, as well as his marriage to his beloved Aarti, because both would be grounded on lies and corruption. With this unexpected twist of events, Gopal is shown to remain at a distance from Balram/Ashok, not only because he does not go as far as committing murder, but also because he ends up sacrificing what he loves most -Aarti- for the sake of sheer honesty. At first sight, this movement is somewhat difficult to believe, as one could think that Gopal could have given up politics yet married Aarti, leaving corruption behind from that moment. But this seems to be an unattainable possibility: The inference of this "moral fable" thus seems to be that, in India at least, it is impossible to stand outside of corruption if one wants to keep certain economic standards.

All in all, then, in the end like Balram/Ashok, Gopal does not appear as a truly debased villain either. On the other hand, a heroic figure is promoted: that of Raghav, founder of the political pamphlet Revolution 2020, which somewhat naively promotes a revolution where Indian youth will rise and overturn the corrupt government and unfair system. It is Raghav who in the end marries Aarti and begins a career in politics, the inference being that he has more chances to redress a deeply polluted system; as polluted, according to Revolution 2020 and The White Tiger, as the holy water of the river Ganga.

\footnotetext{
${ }^{9}$ http://www.adb.org/sectors/water/overview.
} 
How to Get Filthy Rich in Rising Asia takes us to an unnamed city which, given Moshin Hamid's origin, we can situate somewhere in Pakistan, but also anywhere in Asia. There is no holy river this time, but water appears as a crucial resource, getting hold of which means acquiring money and power. Like the city, the successful entrepreneur here is unnamed. He shares with Balram/Ashok and Gopal a poor childhood and scarce possibilities to survive with dignity. Soon orphaned like them, his first employment is already tainted, as it consists of selling "non-expired-labelled expired goods" (Hamid 2013: 99), that is, stale food. Yet he soon begins his own business, consisting of the irregular production and sale of bottled water. This is only the beginning of his economic rise. Devoid here of metaphysical connotations, water appears nonetheless just as necessary, coveted and contaminated as it does in the other two stories:

Your city's neglected pipes are cracking, the contents of underground water mains and sewers mingling, with the result that taps in locales rich and poor alike disgorge liquids that, while for the most part clear and often odourless, reliably contain trace of faeces and microorganisms capable of causing diarrhea, hepatitis, dysentery and typhoid. Those less well off among the citizenry harden their immune systems by drinking freely, sometimes suffering losses in the process, especially of their young and their frail. (Hamid 2013: 99)

In this uncertain landscape, "Those better-off have switched to bottled water" (Hamid 2013: 99), an entrepreneurship niche that our hero is quick to occupy.

Years later, already a millionaire from selling bottled water, he is contacted by members of his country's high spheres and army to be part of a national scheme intended to provide quality water through the tap. The operation, called phase ten, is paramount, pinpointing the value of water: "Phase ten is big," he is told when proposed to be part of the project, "it is bigger than phases one to five put together. Bigger than seven and eight combined. Better than six, and six was huge. Ten is a milestone. A flagship. With ten we are taking it to the next level" (Hamid 2013: 163). As with Shukla Ji's Ganga Action Plan, in this operation public profit, corruption and individual accumulation of 
money are impossible to disentangle. It is difficult to become part of the scheme and not take as much personal profit as possible. Such an idea would actually be nonsense, because

\begin{abstract}
'When we military-related business advance into a market, the front lines change rapidly. We get permissions no one else can get. Red tape dissolves effortlessly for us. And reappears around our competitors. ... And in this case we are going ahead whether you partner with us or not. Better to be close to us that to be yet another incumbent we swat aside. Besides, at least in the near term, we are simply offering you too much cash for you to walk away.'
\end{abstract}

'Yes.' You say inevitably, and as expected. (Hamid 2013: 163-164)

However dubious, plan ten responds to a pressing demand for clean water in the country, which echoes those in other rapidly developing Asian countries. Although it will also mean the possibility for a chosen few to illicitly grow rich (or richer), and unless it is fully sabotaged by corruption and greed as happened to the Ganga Action Plan in Revolution 2020, hopefully its implantation will mean an instrumental improvement in the lives of millions of people. Ironically, thus, in spite of this sordid planning scene, which resolves our protagonist's comfortable future, Plan Ten can be seen to respond to Brahma Chellaney's suggestion that

in an era of growing constraints on augmenting the supply of the most essential resource -water- Asian countries must seek sustainable, cost-effective solutions through collaborative efforts... Competing demands for scarce water resources pose economic, social and political threats that can be contained through forward looking policies ... which depend on linking stakeholders together, collecting reliable data on water resources, and enunciating specific, measurable, attainable, realistic and timely SMART-goals. (Chellaney 2013: 305)

In conclusion, in the three narratives explored here, water figures prominently. Water is used to signify and criticize a relentless progression towards economic development, yet one which ignores the well-being of millions of people, for whom the situation is increasingly worse. Modernization is causing their water to be more polluted and scarce 
than ever, a result of the quick and indiscriminate processes of construction and industrialization. In this conjunction, certain individuals manage to make the most of their also scarce resources and to rise economically, leaving behind those who were like them. And they do so through very dubious methods. These methods, which apparently are those operating in the higher spheres of society, are metaphorically mirrored in the holy waters of the most sacred of the Indian rivers, Mother Ganga. The holy river is presented in two of the novels as a focus of dirt and infection. This problem, which applies to Asian water more generally, ironically creates further possibilities for economic corruption through fake cleaning and purifying schemes. Thus, besides appearing as a necessary and scarce resource for the people, water is still endowed, as in traditional accounts, with a strong symbolic function. The shift from perceiving Mother Ganga as the mythical site of spiritual renewal to realising that it has become the material site of pollution and infection reads as a warning on the part of these authors, that the path to modernity demands a heavy toll, and that modernity does not automatically mean universal inclusion. In the transit from traditional societies, by no means presented as perfect, to more modern ones, the worst lot falls on those occupying the lower ranks of society, whose serious difficulties to survive are aggravated by increasing environmental problems. Only a few chosen individuals -white tigers of their kind- manage to rise above the mud of poverty, destitution and lack of prospects, and their rise takes place only through very controversial means.

It is thanks to these pioneering entrepreneurs that "we gain awareness of a lost people with great potential to change Indian culture" (Waller 2012). Through their engaging and ethically committed narratives, these "Asian-type Horatio Algers" (Mishra 2013) appear as the unofficial spokespersons of a large sector of Indian and Asian societies which is left lagging behind in the vertiginous race of rising Asian economies. These silent masses slowly begin to be heard through the revealing narratives of pioneering figures such as those of Gopal, Balram/Ashok and that unnamed entrepreneur who gets "filthy rich in rising Asia"; that is, those who have managed to rise above the rest and become vocal. Although largely forgotten in official narratives of national enrichment, the silent masses are made visible in these novels. We can trace them in the 
symbolically anonymous hands imprinted on the plaster of Balram's pigsty in the basement he shares with other drivers, where he spends the nights proactively planning the murder and appropriation of his master's wealth and identity. The masses also feature in the thousands of country workers who invest all their life savings in enrolling their elder son in GangaTech so that he may, God willing, become an engineer.

Barely glimpsed through the cracks of these ironic narratives of exceptional success, the anonymous masses are nonetheless full of possibilities. As Pankaj Mishra formulates it,

though largely mute in these dramas of Asian capitalism, the future really belongs to this invisible majority of the "filthy poor"- people who can't even try to enlarge their limits of possibility, but retain the silent potential of weeds that can overrun the world's most zealously maintained gardens. (Mishra 2013, n.p.n.)

As foreseen by Mishra, these silent masses might one day overrun those zealously maintained gardens, and, as Franz Fanon commends and Michel Foucault subscribes, rise against their exploiters. They would then fulfil Fanon's insight that "Decolonization ... transforms spectators crushed with their inessentiality into privileged actors, with the grandiose glare of history's floodlights upon them" (Fanon 1963: 36). This decolonization, which in the $21^{\text {st }}$ century needs to take on an economic rather than a political accent, has so far been only accomplished by a few daring entrepreneurs, the white tigers of their generation, some of whom inhabit the pages of the most incisive of recent Asian fiction.

\section{WORKS CITED}

Adiga, ArAVIND. 2008. The White Tiger. London: Atlantic Books

Al-Dagamseh, AbDullah M. 2013. "Adiga's The White Tiger as World Bank Literature." CLCWeb: Comparative Literature and Culture 15.6. 
ASIAN DEVELOPMENT BANK. http://www.adb.org/sectors/water/overview Access $15 / 10 / 2014$.

ASIAN WATER DEVELOPMENT OUTLOOK 2013. http://www.adb.org/publications/asianwater-development-outlook-2013. Access 15/10/2014.

Aw, TASH. 2013. Five Star Millionaire. New York: Spiegel \& Grau.

BACHELARD, GASTON. 1983. Water and Dreams: An Essay on the Imagination of Matter. Dallas: The Dallas Institute of Humanities and Culture. Trans. Edith R. Farrell.

Bhagat, Chetan. 2011. Revolution 2020. Love. Corruption. Ambition. New Delhi: Rupa Books.

Bodagoya, Randy. 2011. Beggar's Feast. Toronto: Penguin Canada.

BonNEFoy, Yves. 2010 (1981). Diccionario de mitologías. Barcelona: Backlist.

Chellaney, Brahma. 2013. Water: Asia's New Battleground. Washington, D.C.: Georgetown University Press.

Desai, ANITA. 2003 (1980). Clear Light of Day. New Delhi: Atlantic.

DetMERS, INES. 2011. "New India? New Metropolis? Reading Aravind Adiga's The White Tiger as a 'condition-of-India novel'." Journal of Postcolonial Writing Vol. 47, No. 5, December 2011, 535-545.

FAnON, Frantz. 1963. The Wretched of the Earth. New York: Grove Press. Trans. Constance Farrington.

FoucAult, Michel. 1980. "Power, Morals and the Intellectual." An interview conducted by Michael Bes. https://my.vanderbilt.edu/michaelbess/foucaultinterview/ Access 16/10/2014.

Hamid, Moshin. 2013. “How To Get Filthy Rich in Rising Asia.” London: Penguin.

HuA, YU. 2009. Brothers. New York: Pantheon.

JosePh, BetTy. 2012. "Neoliberalism and Allegory." Cultural Critique, Volume 82, Fall 2012, pp. 68-94.

JoShI, DeEPa \& Ben FAWCETT. 2001. "Water, Hindu Mythology and an Unequal Social Order in India." Paper presented at the Second Conference of the International 
Water History Association, Bergen, Germany, August 2001. http://r4d.dfid.gov.uk/PDF/Outputs/R65755.pdf. Access 16/10/2014.

KHOR, LENA. 2012. "Can the Subaltern Right Wrongs?: Human Rights and Development in Aravind Adiga's The White Tiger." South Central Review 29 (1\&2) 41-67.

Mishra, PANKAJ. 2013. “Asia: 'The Explosive Transformation'.” The New York Review of Books. April $25 \quad 2013$ Issue. http://www.nybooks.com/articles/archives/2013/apr/25/asia-explosivetransformation/?pagination=false. Access 8/10/2014

SCHOTLAND, SARAH D. 2011. "Breaking Out the Rooster Coop: Violent Crime in Aravind Adiga's White Tiger and Richard Wright's Native Son." Comparative Literature Studies 48, 1-19.

Sharma, RoBIn. 2007. The Monk Who Sold his Ferrari: A Fable about Fulfilling your Deams and Reaching your Destiny. Mumbai, India: Jaico Publishing House.

2011. The Leader Who Had No Title. Mumbai, India: Jaico Publishing House.

ThOFER, IRFAN. 2012. "Economic Growth: A mirage in India in Aravind Adiga's The White Tiger." Indian Streams Journal. Vol II Iss. IX, p. 1436.

Venugopal, Veena. 2011. "India's Imported Enlightenment.” Publishing Perspectives. June 21，2001. http://publishingperspectives.com/2011/06/indias-importedenlightenment-self-help-bestsellers/

WALLER, KATHLEEN. 2012. "Redefinitions of India and Individuality in Adiga's The White Tiger." CLCWeb: Comparative Literature and Culture 14.2. 